\title{
Effect of di-calcium phosphate on calcium balance and body condition score of dairy cows fed Napier grass
}

\author{
MZ Rahman, MY Ali*, KS Huque, MAI Talukder
}

Bangladesh Livestock Research Institute, Savar, Dhaka 1341, Bangladesh

\begin{abstract}
A research work was undertaken to evaluate the feeding effects of di-calcium phosphate (DCP) on calcium balance and body condition score of dairy cows fed Napier grass. The trial was conducted in the village Alokdiar of Shajadpur upazilla under Sirajgonj district. Twenty crossbred lactating dairy cows of $320 \pm 15.5 \mathrm{~kg}$ live weight were used for the trial. Animals were equally and randomly allocated into four groups, $T_{0}$ (Napier+concentrate), $T_{1}$ (Napier+concentrate+100g DCP), $T_{2}$ (Napier+concentrate+150g $\mathrm{DCP})$ and $\mathrm{T}_{3}$ (Napier+concentrate+200g DCP). Total DMI did not differ significantly $(p>0.05)$ among the groups but highly significant differences $(p<0.01)$ were found in Ca intake. Ca balance; and Ca in feces, $\mathrm{Ca}$ in urine, $\mathrm{Ca}$ in milk and total $\mathrm{Ca}$ excretion differed significantly $(\mathrm{p}<0.05)$. No significant difference $(p>0.05)$ was found in DM in feces (\%), DM in feces $(\mathrm{kg} / \mathrm{d})$ and milk production (L) among the treatment groups except urine excretion. There was a linear increase of body condition score (BCS) with $\operatorname{DCP}\left(T_{1}, T_{2}\right.$ and $\left.T_{3}\right)$, but BCS was linearly declined in non DCP diet $\left(T_{0}\right)$. Diets with $150 \mathrm{~g}$ DCP may be suggested for optimizing Calcium balance and body condition score of dairy cows fed Napier grasses.
\end{abstract}

Key words: Body condition score, calcium excretion, dairy cows, di-calcium phosphate

Bangladesh Animal Husbandry Association. All rights reserved. Bang. J. Anim. Sci. 2014.43 (3): 197-201

\section{Introduction}

The scarcity of quality fodders is one of the major problems in Bangladesh for rearing dairy cows. To mitigate this problem, Bangladesh Livestock Research Institute (BLRI) introduced Napier grass (Pennisetum purpureum) in the Pabna and Sirajgonj districts during 1988 to 2005, two most important milk pocket areas of Bangladesh. Despite increased daily milk production farmers complained that feeding fresh Napier grass(Pennisetum purpureum) resulted weakness and poor body condition (Huque et al. 2006) which is caused due to drainage of $\mathrm{Ca}$ in the form of calcium oxalate through the urine and feces at high rate of $25.28 \mathrm{~g} / \mathrm{d}$ (Das et al. 2010). This might also be due to the presence of oxalate in the grass and feeding Napier to cows might lead to ingestion of oxalate above their dietary tolerance level $(<2.0 \%)$ which might have an effect on mineral metabolism of these animals. Rahman et al. (2006) found that the oxalate content of the Napier was as high as $3.77 \%$ of the dry matter in early summer season (September - October). Since Napier grass is such an important forage species for animals throughout the tropics and sub-tropics because most of the dairy animals in our country depends on fresh grass, its soluble oxalate concentrations are of concern, being reported as relatively high (<3\%) (Garcia-Rivera and Morris 1955; Lal et al. 1966; Dhillon et al. 1971), and sometimes exceeding $3.77 \%$ of the dry matter (Rahman et al. 2006). Although plants can tolerate significant amounts of oxalate in tissues during the different stages of growth, high oxalate levels in plants have long been a significant concern for animal nutritionists, because of the negative health effects like lower body condition score associated with high intake of oxalate. Soluble oxalate can bind with calcium in the intestines and in the blood to form insoluble calcium oxalate crystals, lowering serum calcium levels. McKenzie et al. (1988) reported that $2 \%$ or more soluble oxalate can lead to acute toxicosis in ruminants. Although rumen bacteria can adapt to a high levels of soluble oxalate in the diet (Allison et al. 1977), sometimes acute toxicity occurred even in adapted ruminants fed with kikuyu grass containing relatively low oxalate $(3.9-24.4 \mathrm{~g} / \mathrm{kg}$ DM) concentrations (Marais 2001). While soluble oxalate is destroyed in the rumens of adapted 


\section{Calcium balance and body condition score of dairy cows}

animals, insoluble oxalate seems to pass through the digestive tract (Ward et al. 1979), though Libert and Franceschi (1987) reported that a substantial portion of calcium oxalate in the feed could be dissolved during digestion in ruminants. The role of insoluble oxalate in animals is not well understood. The present work was undertaken to determine the effect di-calcium phosphate (DCP) on Calcium balance and body condition score for optimizing the milk production of dairy cows fed Napier grass.

\section{Materials and Methods}

The research was conducted in the village Alokdiar, Shajadpur, Sirajgonj. The duration of the experiment was six months (November 2012 to April 2013). Twenty crossbred lactating dairy cows (of $1^{\text {st }}$ lactation) were selected for using in this trial. The average body weight and milk production were $320 \pm 15.5 \mathrm{~kg} / \mathrm{cow}$ and 10 lit./d/cow, respectively. The animals were randomly distributed in four groups $\left(T_{0}, T_{1}, T_{2}\right.$ and $T_{3}$ ) each having five animals. The animal grouping was done according to live weight $(\mathrm{kg})$ and milk production $(\mathrm{l} / \mathrm{d})$. The animals were housed individually in loose shed. The animals were de-wormed with the LT-Zol-Vet (product of Popular Agrovet Ltd. Gazipur, Bangladesh), ear tagged and allowed for 14 days to adjust with the experimental diets and management prior to the commencement of the trial.

Four diets were prepared as: $\mathrm{T}_{0}$ (Napier + concentrate), $\mathrm{T}_{1}$ (Napier + concentrate $+100 \mathrm{~g}$ $\mathrm{DCP}), \mathrm{T}_{2}$ (Napier + concentrate $+150 \mathrm{~g}$ DCP) and $\mathrm{T}_{3}$ (Napier + concentrate $+200 \mathrm{~g} \mathrm{DCP}$ ). The concentrate part of the ration was composed of wheat bran $(30 \%)$, rice polish $(20 \%)$, crushed maize $(10 \%)$, khesari bran $(15 \%)$, soyabean meal $(10 \%)$, til oil cake $(12.5 \%)$ and salt $(2.5 \%)$. The concentrate mixture contained $18 \% \mathrm{CP}$ and 10.31 MJ ME/kg DM. (by proximate analysis). Fresh and clean drinking water was supplied for all the animals. In case of $\mathrm{T}_{1}, \mathrm{~T}_{2}$ and $\mathrm{T}_{3}$ groups, DCP was properly mixed with the concentrate mixture and then supplied to the animals. The daily requirement of feed was divided into two parts equally for feeding the animals in the morning at 7:00 $\mathrm{AM}$ and in the afternoon at
16:00 PM. Concentrate was supplied first followed by Napier grass.

Refusal of feed and Napier grass was collected every morning and weighed to determine daily intake. During the experimental period, the animals consumed all of the concentrate. Output of feces and urine were recorded daily during the last 7 days of the feeding trial period out of 159 days. The quantity of feed, refusal (Napier grass- $20 \mathrm{~kg}$ ) and feces were weighed daily and representative samples were kept for analysis. Milk was collected in every morning and evening during feeding trial. Feces and urine were collected daily which was started at every 8:00 am and weighed after every 24 hours for 7 days and sub-sample was taken every day from each animal. Samples of feces were collected in plastic bags and kept in the freezer $\left(-20{ }^{\circ} \mathrm{C}\right)$ (ESCO company Itd). Urine sample was collected in a bucket containing $6 \mathrm{~N} \mathrm{H}_{2} \mathrm{SO}_{4}$ solution (purity 98\% provided by Sigma Aldrich Int. Co. Itd., Bangladesh) to maintain a $\mathrm{pH}$ of 4 or lower and taken $10 \%$ sub-sample and stored at $-20{ }^{\circ} \mathrm{C}$ until analyzed.

All the samples and sub-samples of feed, feces, milk and urine were used for analysis. The samples were subjected to chemical analysis for the determination of dry matter (DM), organic matter (OM) and ash following the methods of AOAC (1995). Calcium content was determined by Atomic Absorption Spectrometry (Japan) method (Varma, 1985); using Atomic Absorption Spectrophotometer. All the samples were analyzed in two times and the mean values were recorded.

The chemical composition of feeds used in the trial is given in Table 1 . The $\mathrm{Ca}$ contents of Napier grass and concentrate mixture was 0.40 and $0.97 \%$, respectively.

Table 1. Chemical composition of feed stuffs

\begin{tabular}{lcccc}
\hline \multirow{2}{*}{ Feed } & \% fresh & \multicolumn{3}{c}{ \% DM basis } \\
\cline { 2 - 5 } ingredients & $\mathrm{DM}$ & $\mathrm{OM}$ & Ash & $\mathrm{Ca}$ \\
\hline Napier grass & $19 . .98$ & 89.75 & 10.25 & 0.40 \\
Concentrates & 91.43 & 91.13 & 8.87 & 0.97 \\
\hline
\end{tabular}


Rahman et al. (2014) Bang. J. Anim. Sci. 43 (3): 197- 201

BCS are positively related to future success in conception, and avoidance of dystocia and retained placenta and other illnesses (Delgado et al. 2004; Morris et al. 2006; Jilek et al. 2008). The ovulation rate of females increases with body condition (or liveweight), and the post-partum anoestrus interval is reduced when cows calve at higher BCS (Markusfeld et al. 1997). Fatcorrected lactation yield is related to BCS at calving (Berry et al. 2007; de Freitas et al. 2008), and calves born to cows with lower BCS may be less viable than those born to cows with higher BCS (Ezanno et al. 2005). For these reasons, cows should reach a BCS of 3 or 3.5 (5-point scale) prior to mating and calving.

The statistical analysis was done using 'SPSS11.5 ' statistical program to compute analysis of variance in completely randomized design. Differences among the treatment means were determined by Duncan's Multiple Range Test.

\section{Results and discussion}

Total dry matter intake DMI did not differ significantly $(p>0.05)$ among the treatment groups. Highly significant differences $(p<0.01)$ were found in case of $\mathrm{Ca}$ intake $\& \mathrm{Ca}$ balance. Ca in feces, urine and milk differed significantly $(p<0.05)$ among the treatment groups (Table 2$)$. With the increase of DCP intake, there was a highly significant $(p<0.01)$ increase of Ca intake (56.82, 78.17, 94.89 and $110.57 \mathrm{~g} / \mathrm{d}$ in $\mathrm{T}_{0}, \mathrm{~T}_{1}$, $T_{2}$ and $T_{3}$, respectively) and subsequent increase $(p<0.01)$ of their Ca balance $(2.94,28.93,36.70$ and $42.71 \mathrm{~g} / \mathrm{d}$ in $\mathrm{T}_{0}, \mathrm{~T}_{1}, \mathrm{~T}_{2}$ and $\mathrm{T}_{3}$, respectively). $C a$ in feces was higher $(p<0.05)$ in $\mathrm{T}_{3}$ followed by $T_{2}, T_{0}$ and $T_{1}(51.40,43.39,43.10$ and 34.92 $\mathrm{g} / \mathrm{d}$, respectively). Ca was also significantly higher in urine $(p<0.05)$ in $T_{0}$ followed by $T_{1}, T_{2}$ and $T_{3}$ $(3.16,2.89,2.50$ and $2.08 \mathrm{~g} / \mathrm{d}$, respectively) and total $\mathrm{Ca}$ excretion higher $(\mathrm{p}<0.05)$ in $\mathrm{T}_{3}$ followed by $T_{2}, T_{0}$ and $T_{1}(67.86,58.19,53.88$ and 49.24 $g / d$, respectively). Ca in milk of $T_{1}, T_{2}$ and $T_{3}$ were not differ significantly $(p>0.05)$ but they differ significantly from $T_{0}(p<0.05)$. Increasing level of di-calcium phosphate in $T_{1}, T_{2}$ and $T_{3}$ diets increased calcium intake and resulted in higher calcium retention in the body compared to $\mathrm{T}_{0}$.
Table 2. Ca balance (Mean \pm SE) in dairy cows

\begin{tabular}{|c|c|c|c|c|c|}
\hline Parameters & $\mathrm{T}_{0}$ & $\mathrm{~T}_{1}$ & $\mathrm{~T}_{2}$ & $\mathrm{~T}_{3}$ & $\begin{array}{l}\text { Sig. } \\
\text { level }\end{array}$ \\
\hline $\begin{array}{l}\text { Total DMI } \\
(\mathrm{kg} / \mathrm{d})\end{array}$ & $\begin{array}{c}8.78 \\
\pm 0.78\end{array}$ & $\begin{array}{c}8.41 \\
\pm 0.88\end{array}$ & $\begin{array}{c}8.34 \\
\pm 0.97\end{array}$ & $\begin{array}{c}8.70 \\
\pm 0.82\end{array}$ & NS \\
\hline $\begin{array}{l}\text { Total Ca intake } \\
\text { (g/d) }\end{array}$ & $\begin{array}{l}56.82^{\mathrm{d}} \\
\pm 6.86\end{array}$ & $\begin{array}{l}78.17 \mathrm{c} \\
\pm 9.67\end{array}$ & $\begin{array}{l}94.89 \mathrm{bc} \\
\pm 10.33\end{array}$ & $\begin{array}{l}110.57^{\mathrm{a}} \\
\pm 12.22\end{array}$ & 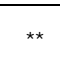 \\
\hline $\begin{array}{l}\text { Ca in feces } \\
(\mathrm{g} / \mathrm{d})\end{array}$ & $\begin{array}{c}43.10^{\mathrm{abd}} \\
\pm 4.46\end{array}$ & $\begin{array}{l}34.92^{c} \\
\pm 3.96\end{array}$ & $\begin{array}{l}43.39 \mathrm{ab} \\
\pm 5.75\end{array}$ & $\begin{array}{l}51.40^{\mathrm{a}} \\
\pm 6.21\end{array}$ & * \\
\hline $\begin{array}{l}\text { Ca in urine } \\
\text { (g/d) }\end{array}$ & $\begin{array}{r}3.16^{\mathrm{a}} \\
\pm 0.36 \\
\end{array}$ & $\begin{array}{l}2.89 \mathrm{~b} \\
\pm 0.23\end{array}$ & $\begin{array}{r}2.50^{c} \\
\pm 0.29\end{array}$ & $\begin{array}{l}2.08^{d} \\
\pm 0.34\end{array}$ & * \\
\hline Ca in milk $(\mathrm{g} / \mathrm{d})$ & $\begin{array}{l}7.62^{\mathrm{b}} \\
\pm 0.39\end{array}$ & $\begin{array}{l}11.43 \mathrm{a} \\
\pm 0.72\end{array}$ & $\begin{array}{l}12.30 \text { a } \\
\pm 0.98\end{array}$ & $\begin{array}{l}14.38^{a} \\
\pm 0.78\end{array}$ & * \\
\hline $\begin{array}{l}\text { Total Ca } \\
\text { excretion (g/d) }\end{array}$ & $\begin{array}{l}53.88^{\mathrm{cd}} \\
\pm 5.32\end{array}$ & $\begin{array}{l}49.24 \text { bc } \\
\pm 4.62\end{array}$ & $\begin{array}{l}58.19 \mathrm{ab} \\
\pm 3.97\end{array}$ & $\begin{array}{l}67.86^{a} \\
\pm 5.31\end{array}$ & * \\
\hline $\begin{array}{l}\text { Ca balance } \\
(\mathrm{g} / \mathrm{d})\end{array}$ & $\begin{array}{l}2.94^{\mathrm{d}} \\
\pm 0.24\end{array}$ & $\begin{array}{l}28.93^{\mathrm{cb}} \\
\pm 2.67\end{array}$ & $\begin{array}{l}36.70^{\mathrm{ab}} \\
\pm 3.43\end{array}$ & $\begin{array}{l}42.71^{\mathrm{a}} \\
\pm 4.21\end{array}$ & *夫 \\
\hline
\end{tabular}

*, $p<0.05) ; * *, p<0.01$; Means with different superscripts in the same row differed significantly; NS, not significant; $T_{0}$, Napier+concentrate; $T_{1}$, Napier+concentrate+100g DCP; $T_{2}$, Napier+concentrate $+150 \mathrm{~g}$ $D C P ; T_{3}$, Napier+concentrate+200g DCP

The result of this study is supported by Das et al. (2010). He reported that the increased oxalate intake resulted in an increased $\mathrm{Ca}$ intake, in feces, urine and total excretion but decreased $\mathrm{Ca}$ balance of animals fed Napier. James and Butcher (1972) also reported that the increased oxalate intake resulted in an increased calcium excretion in feces of crossbred sheep fed different levels of oxalate in the form of Halogeton.

Non-significant difference ( $p>0.05)$ was found in case of DM in feces (\%), DM in feces $(\mathrm{kg} / \mathrm{d})$ and milk production among the treatment groups except urine excretion (Table 3 ). Urine excretion among $T_{1}, T_{2}$ and $T_{3}$ did not differ significantly ( $p>0.05)$ but when these diets compared with non DCP diet $\left(T_{0}\right)$ the difference was highly significant $(p<0.01)$ between DCP diets and non DCP diet (19.26, 11.86, 11.76 and $11.47 \mathrm{~g} / \mathrm{d}$ for $\mathrm{T}_{0}, \mathrm{~T}_{1}, \mathrm{~T}_{2}$ and $\mathrm{T}_{3}$ diets, respectively).

Huque et al. (2006) reported that feeding fresh Napier grass results increased urination and soft dung. Das et al. 2010 also found increased level of DM in feces (\%) and DM in feces $(\mathrm{kg} / \mathrm{d})$ after feeding increasing amount of oxalate through Napier grass. Chang et al. (2004) stated that feeding increasing amount of oxalate through Napier grass increased DM content with the 


\section{Calcium balance and body condition score of dairy cows}

reduction of water content in feces. James and Butcher (1972) stated that feeding oxalate at an increasing level might have an effect on increased urine production. Napier diets failed to supply required amount of calcium for both maintenance and production.

Table 3. Effects of DCP intake on milk production, feces and urine excretion (Mean \pm SE)

\begin{tabular}{lcccc}
\hline Parameters & $\mathrm{T}$ & $\mathrm{T}_{1}$ & $\mathrm{~T}_{2}$ & $\mathrm{~T}_{3}$ \\
\hline \multirow{2}{*}{ Milk production (L/d) } & 9.45 & 10.69 & 10.48 & 11.76 \\
& \pm 1.42 & \pm 0.98 & \pm 1.31 & \pm 1.61 \\
\hline \multirow{2}{*}{ DM in feces (\%) } & 18.22 & 20.03 & 19.93 & 19.88 \\
& \pm 0.91 & \pm 1.02 & \pm 0.92 & \pm 0.88 \\
\hline \multirow{2}{*}{ DM in feces (kg/d) } & 3.04 & 3.12 & 2.83 & 2.96 \\
& \pm 0.16 & \pm 0.14 & \pm 0.09 & \pm 0.11 \\
\hline \multirow{2}{*}{ Urine excretion (L/d) } & $19.26^{\mathrm{a}}$ & $11.86^{\mathrm{b}}$ & $11.76^{\mathrm{b}}$ & $11.47 \mathrm{~b}$ \\
& \pm 2.23 & \pm 1.25 & \pm 1.33 & \pm 1.51 \\
\hline
\end{tabular}

Means with different superscripts in the same row differed significantly $(p<0.01) ; T_{0} ;$ Napier + concentrate, $T_{1}$, Napier + concentrate + $100 \mathrm{~g} D C P ; T_{2}$, Napier + concentrate + 150g DCP; $T_{3}$, Napier + concentrate $+200 \mathrm{~g} D C P$

It is apparent from Figure 1 that there was a linear increase of body condition score (BCS) in case of di-calcium phosphate diets $\left(T_{1}, T_{2}\right.$ and $\left.\mathrm{T}_{3}\right)$, but BCS was linearly declined in case of non $\mathrm{DCP}$ diet $\left(\mathrm{T}_{0}\right)$.

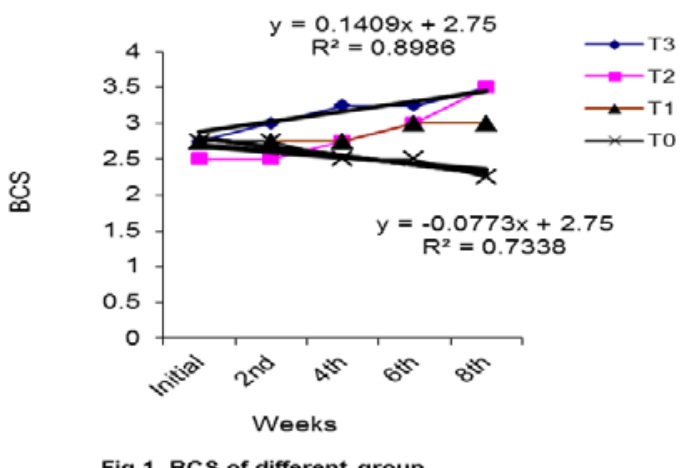

The BCS was better in $T_{3}$ followed by $T_{2}, T_{1}$ and $T_{0}$. Calcium balances of the non DCP diet/Napier diet $\left(T_{0}\right)$ failed to support body requirement and prolonged feeding which may affect the BCS. The higher reduction of calcium balance may affect on BCS of dairy cows. The BCS was better in $T_{3}$ followed by $T_{2}, T_{1}$ and $T_{0}$. Poor body condition and weakness was also observed by Huque et al.
(2006) in animals fed fresh Napier grass. Das et al. (2010) found that the oxalate content of Napier silage may significantly reduce the balance of calcium and phosphorus in bulls that may cause retarded growth and poor body condition of bulls.

\section{Conclusion}

From the findings it could be suggested that $150 \mathrm{~g}$ di-calcium phosphate may be used for optimizing Calcium balance and body condition score of dairy cows fed Napier grasses.

\section{References}

Allison MJ, Littledike ET, James LF (1977). Changes in ruminal oxalate degradation rates associated with adaptation of oxalate ingestion. Journal of Animal Science, 45, 1173-1179.

AOAC (1995). Official Methods of Analysis. (16 $6^{\text {th }}$ edition), Association of Official Analytical Chemist. Washington DC.

Berry DR, Buckley F, Dillon R (2007). Body condition score and live-weight effects on milk production in Irish Holstein-Friesian dairy cows. Animal, 1:1351-1359.

Das NG, Huque KS, Alam MR, Sultana N, Amanullah SM (2010). Effects of oxalate intake on calcium and phosphorus balance in bulls fed Napier silage (Penneisetum purpureum). Bangladesh Journal of Animal Science, 39: 58-66.

Dhillon KS, Paul BS, Bajwa RS, Singh J (1971). A preliminary report on a peculiar type of napiergrass (Pennisetum purpureum, 'Pusa giant') poisoning in buffalo calves. Indian Journal of Animal Sciences, 41, 10341036.

Delgado R, Magana JG, Galina C, Segura JC (2004). Effect of body condition at calving and its changes during early lactation on postpartum reproductive performance of Zebu cows in a tropical environment. Journal of Applied Animal Research, 26:2328.

Ezanno P, Ickowicz A, Lancelot R (2005). Relationships between N'Dama cow body condition score and production performance under an extensive range management system in Southern Senegal: 
Rahman et al. (2014) Bang. J. Anim. Sci. 43 (3): 197- 201

calf weight gain, milk production, probability of pregnancy, and juvenile mortality. Livestock Production Science, 92: 291-306.

Garcia-Rivera J and Morris MP (1955). Oxalate content of tropical forage grasses. Science, 122, 1089-1090.

Chang HW, Chi WD, Shyuan YS, Yukuel C (2004). Comparison of different oxalate contents of Napier grass fed to yellow cattle and goats. Journal of Taiwan Livestock Research, 37: 313-322.

Huque KS, Amanullah SM, Islam MM (2006). Impacts of fodder crop introduction into farming systems of selected areas on smallholder dairy development in Bangladesh. Annual Report (2005 and 2006). Bangladesh Livestock Research Institute, Savar, Dhaka 1341, 107-109.

James LF, Butcher JE (1972). Halogeton poisoning of sheep: Effect of high level oxalate intake. Journal of Animal Science, 35: 1233-1238.

Lal BM, J ohari RP, Mehta RK (1966). Some investigations on the oxalate status of Pusa giant napier grass and its parents. Current Science, 5: 125-126.

Libert B, Franceschi VR (1987). Oxalate in crop plants. Journal of Agriculture and Food Chemistry, 35: 926-938.
Marais JP (2001). Factors affecting the nutritive value of kikuyu grass (Pennisetum clandestinum) - a review. Tropical Grasslands, 35: 65-84.

Mckenzie RA, Bell AM, Storie GJ, Keenan FJ, Cornack KM, Grant SG (1988). Acute oxalate poisoning of sheep by buffelgrass (Cenchrus ciliaris). Australian Veterinary Journal, 65: 26.

Rahman MM, Niimi M, Ishii Y, Kawamura O (2006). Effects of season, variety and botanical fractions on oxalate content of napier grass (Pennisetum purpureum Schumach). Grassland Science, 52: 161166.

Soares FS, Dryden GMD (2011). Body condition scoring system for Bali cattle. AsianAustralasian J ournal of Animal Science, 24: 1587- 1594.

Varma A (1985). Handbook of Atomic Absorption Analysis. Volume 1, CRC Press, Boca Ration, India.

Ward GL, Harbers H, Blaha JJ (1979). Calcium containing crystals in alfalfa: their fate in cattle. Journal of Dairy Science, 62: 715722. 